\title{
Identifying mRNA targets of microRNA dysregulated in cancer: with application to clear cell Renal Cell Carcinoma
}

\author{
Huiqing Liu1,11, Angela R Brannon², Anupama R Reddy¹, Gabriela Alexe³, Michael W Seiler1', Alexandra Arreola2, \\ Jay H Oza4, Ming Yao4, David Juan5, Louis S Liou,5,6, Shridar Ganesan4, Arnold J Levine7, WK Rathmell*2,8 and \\ Gyan $\vee$ Bhanot*1,4,7,9,10
}

\begin{abstract}
Background: MicroRNA regulate mRNA levels in a tissue specific way, either by inducing degradation of the transcript or by inhibiting translation or transcription. Putative mRNA targets of microRNA identified from seed sequence matches are available in many databases. However, such matches have a high false positive rate and cannot identify tissue specificity of regulation.

Results: We describe a simple method to identify direct mRNA targets of microRNA dysregulated in cancers from expression level measurements in patient matched tumor/normal samples. The word "direct" is used here in a strict sense to: a) represent mRNA which have an exact seed sequence match to the microRNA in their $3^{\prime} U T R, b$ ) the seed sequence match is strictly conserved across mouse, human, rat and dog genomes, c) the mRNA and microRNA expression levels can distinguish tumor from normal with high significance and d) the microRNA/mRNA expression levels are strongly and significantly anti-correlated in tumor and/or normal samples. We apply and validate the method using clear cell Renal Cell Carcinoma (ccRCC) and matched normal kidney samples, limiting our analysis to mRNA targets which undergo degradation of the mRNA transcript because of a perfect seed sequence match. Dysregulated microRNA and mRNA are first identified by comparing their expression levels in tumor vs normal samples. Putative dysregulated microRNA/mRNA pairs are identified from these using seed sequence matches, requiring that the seed sequence be conserved in human/dog/rat/mouse genomes. These are further pruned by requiring a strong anticorrelation signature in tumor and/or normal samples. The method revealed many new regulations in ccRCC. For instance, loss of miR-149, miR-200c and mir-141 causes gain of function of oncogenes (KCNMA1, LOX), VEGFA and SEMA6A respectively and increased levels of miR-142-3p, miR-185, mir-34a, miR-224, miR-21 cause loss of function of tumor suppressors LRRC2, PTPN13, SFRP1, ERBB4, and (SLC12A1, TCF21) respectively. We also found strong anticorrelation between VEGFA and the miR-200 family of microRNA: miR-200a*, 200b, 200c and miR-141. Several identified microRNA/mRNA pairs were validated on an independent set of matched $c c R C C /$ normal samples. The regulation of SEMA6A by miR-141 was verified by a transfection assay.

Conclusions: We describe a simple and reliable method to identify direct gene targets of microRNA in any cancer. The constraints we impose (strong dysregulation signature for microRNA and mRNA levels between tumor/normal samples, evolutionary conservation of seed sequence and strong anti-correlation of expression levels) remove spurious matches and identify a subset of robust, tissue specific, functional mRNA targets of dysregulated microRNA.
\end{abstract}

\footnotetext{
*Correspondence: rathmell@med.unc.edu, gyanbhanot@gmail.com

2 Lineberger Comprehensive Cancer Center, University of North Carolina, Chapel Hill, NC 27599, USA

2 BioMaPS Institute, Rutgers University, Piscataway, NJ 08854, USA

Full list of author information is available at the end of the article
}

\section{Background}

MicroRNA regulate mRNA and protein levels by cleavage and/or translation/transcriptional repression in a tissue specific manner [1-4]. By modulating key cellular processes such as metabolism, division, differentiation, 
development and apoptosis, they can simultaneously regulate both oncogenes and tumor suppressor genes [5-7]. Aberrant microRNA profiles have been noted in many cancers [5-11], including renal cell carcinoma [12-16]. Almost half the known microRNAs are in cancer-associated chromosomal fragile sites, susceptible to point mutation, amplification, deletion, or translocation $[17,18]$. Recent evidence demonstrates that microRNA play an important role in the patho-physiology of many cancers [19-22] and they are believed to be involved in pathogenesis in ccRCC $[20,23]$. MicroRNA are also being studied in various tumors to understand their significance for drug resistance [24,25], diagnosis and prognosis [26-28] and for their therapeutic potential [29-40]. Their secondary structure preserves them better in FFPE samples than mRNA, making them easier to extract in intact form, resulting in higher identification accuracy in the analysis of archived clinical material [35]. Their tissue specificity and tight regulation makes them more reliable identifiers of tissue of origin in highly differentiated tumors [41]. Single microRNA can regulate multiple mRNA and are therefore both better identifiers of mechanism and possibly better drug targets [4]. However, while it is clear that microRNA play an important role in the biology of many cancers, their complex biology and tissue specificity makes it difficult to understand the precise role they play in the disease process and the genes affected by their dysregulation [42-47].

Mature microRNAs are produced in a multi-stage process. After transcription, they are processed by RNA Pol II or Pol III to create capped and polyadenylated primary transcripts (Pri-microRNAs), which are further processed in the nucleus by the enzyme Drosha/Pasha (in flies) or by DGCR8 (in humans) to produce $~ 60$-nucleotide Pre-microRNA stem-loop molecules. These are then exported to the cytoplasm by Exportin and RanGTP where they are further processed by Dicer to $\sim 22 \mathrm{nt}$ double-stranded RNA duplexes, which form complexes with RISC (RNA-induced silencing complex) leading to unwinding of the duplexes to form single-stranded microRNAs. MicroRNAs bound to RISC can down-regulate protein levels using at least two alternative pathways: 1) If the microRNA has imperfect complementarity with a matching sequence in the 3'UTR of its target mRNA, the microRNA-RISC complex can combine with the complement mRNA sequence and cause translational repression. 2) On the other hand, if the microRNA and its mRNA target have perfect or near perfect complementarity, the microRNA-RISC complex binding to its target mRNAs can result in the cleavage and degradation of the mRNA by Argonaute2 (Ago2) [1-7,35].

Although many studies have identified signatures of microRNA dysregulation, the identification of tissue specific targets of aberrantly regulated microRNA is difficult.
Putative identification using seed sequence complementarity and free energy predictions of RNA-RNA duplexes [48-55] are available in databases such as TargetScan: http://www.targetscan.org. However, the false positive rate for such matches is unacceptably high, with different algorithms identifying different mRNA targets for the same microRNA [51-53,56,57]. The tissue specificity of microRNA regulation is known only in some specific cases (e.g. see Table one in [58]) and a general methodology for target identification, tissue specificity of action and specific biological role of microRNA in the initiation and progression of most cancers remains an open problem.

We describe a novel method to identify "direct mRNA targets" of microRNA in any cancer based on measuring an anti-correlation signal between differentially expressed microRNA and mRNA in patient matched tumor and normal samples. In this paper, the words "direct mRNA targets" is used in a very strict and limited sense. A direct target is one which: a) has an exact seed sequence match in its 3'UTR to the corresponding microRNA, b) the seed sequence match is conserved across mouse, human, rat and dog genomes, c) the expression levels of both the microRNA and the mRNA can distinguish tumor from normal with high statistical significance and d) the mRNA and microRNA levels are strongly and significantly anti-correlated in tumor and/or normal. These requirements could be relaxed to find additional targets or eliminated altogether to find indirect regulations (see later discussion).

The method proceeds as follows: a) Identify significantly differentially expressed microRNA and mRNA between the two classes (e.g. normal and tumor); b) For each microRNA which is differentially expressed, identify all its putative target mRNA by restricting to those differentially expressed mRNA with a matching seed sequence in their 3'UTR, with the further requirement that it be conserved in human, mouse, rat and dog genomes; c) Compute the Pearson correlation between microRNA and mRNA expression levels for samples in each class (tumor and normal) and d) Retain only those microRNA/ mRNA pairs whose expression levels are highly anti-correlated. These constraints remove spurious matches, reducing relatively speculative "putative" seed match based mRNA targets in databases to a highly robust subset of direct functional targets.

Note that our method can be extended (with data on more samples) by removing constraint b) and looking for a correlation (or anti-correlation) signature in c). This allows the identification of indirect regulation. For example, if a microRNA up-regulated in cancer down-regulates a gene which is a transcriptional repressor of an oncogene, then the expression level of the microRNA will be correlated with the level of the oncogene without a 
seed sequence match. Since the direct gene target (the transcriptional repressor in the example above) of the microRNA should already be identified using our method, such an analysis would extend the regulation network beyond first order interactions. Note that, although the method as described above does not identify regulation by translation inhibition (because this would not significantly affect mRNA levels), if protein levels were also measured, the method could easily be extended to identify such regulation.

We demonstrate the use of our method on expression data from clear cell Renal Cell Carcinoma (ccRCC) and matched normal kidney samples. Renal Cell Carcinoma (RCC) represents $\sim 3 \%$ of all malignancies in the US, with 50,000 new cases and 12,000 deaths each year http:// www.nci.nih.gov/cancertopics/types/kidney. The most common histological class is ccRCC, accounting for $\sim 75 \%$ of kidney cancers. ccRCC is known to be characterized by the loss of the VHL gene, which under normal oxygen pressure, binds to the $\alpha$ subunits of hypoxiainducible factors (HIFs), inducing their poly-ubiquitinylation and subsequent degradation in the proteasome. In hypoxic conditions, or if HIF regulation is lost because of VHL inactivation, HIF accumulates to high levels and promotes the transcription of genes such as VEGF, PDGF- $\beta$, TGF- $\alpha$, EPO etc which trigger angiogenesis, cell growth, migration and proliferation $[59,60]$. The spectrum of HIF target genes expressed in individual tumors and the factors which influence them are the object of active ongoing research. ccRCC tumors have a wide range of natural histories and varied responses to VEGF-targeted therapy [61]. Early stage, Fuhrman grade 1 (low grade) tumors tend to have significantly better disease free survival after resection than higher stage and grade (Fuhrman grade 4) [62]. Although VHL mutation is associated with all grades of ccRCC, the other molecular factors associated with ccRCC initiation and progression are largely unknown. The molecular basis of the diversity in histologic grade, clinical behavior, and response to VEGF-targeted is also unclear, and makes ccRCC a ripe target for studies investigating the molecular and genetic nature of these heterogeneities.

In RCC, various studies have identified panels of microRNA and mRNA that are differentially expressed between normal renal tissue and tumor or between histological subtypes of tumor [12,14,15,63-66]. The present study extends these previous studies by linking the microRNA to some of their mRNA targets, thus elucidating a hitherto unknown part of the biology of ccRCC disease. Some of the identified microRNA/mRNA anticorrelations were validated on a new cohort of ccRCC/ normal samples. SEMA6A was confirmed as a direct target of miR-141 by over-expressing miR-141 in a ccRCC cell line and showing strong down-regulation of the SEMA6A transcript.

\section{Results}

The underlying hypothesis in our method is that the expression levels of microRNA and their direct mRNA targets should be strongly anti-correlated when averaged over matched samples in either tumor or normal tissue. The stepwise procedure is as follows:

Step 1: Identify significantly up/down regulated microRNAs in ccRCC samples vs normal samples.

Step 2: Identify significantly up/down regulated mRNAs in ccRCC samples vs normal samples.

Step 3: Using TargetScan, retain only the mRNA in Step 2 which have a conserved seed sequence in their 3' UTR for at least one of the microRNA from Step 1. Step 4: Find anti-correlated pairs of up-regulated microRNA and down-regulated mRNA in ccRCC samples using a strict cutoff $\left(\mathrm{P}_{0}\right)$ in Pearson correlation coefficient in ccRCC samples. Similarly, find anti-correlated pairs of down-regulated microRNA and up-regulated mRNAs in normal kidney samples using a strict cutoff.

In Step 3, putative target mRNA were identified using TargetScan Version 4.1 http://www.targetscan.org, which identifies possible regulatory targets of mammalian microRNAs as those with conserved sequences of matching seed regions for each microRNA. The term "conserved" means that the sequence is conserved in human, mouse, rat and dog. In Step 4, we ran 1000 permutations in BRB-ArrayTools' http://linus.nci.nih.gov/BRB-ArrayTools.html and multivariate/univariate analysis at $p<$ $0.01, \mathrm{FDR}<0.2$ to assess significance of discovered pairs and to find the appropriate cutoff $\mathrm{P}_{0}$ for significance of the measured Pearson correlation. In the primary dataset, because of the high accuracy of qRT-PCR, we were able to set a strict cutoff $\mathrm{P}_{0}=-0.95$; thus in Step 4 only microRNA/mRNA pairs with $\mathrm{P}<\mathrm{P}_{0}(=-0.95)$ were considered to be significant.

\section{Step 1: MicroRNA significantly differentially expressed in cCRCC versus normal kidney tissue}

35 microRNA were identified as differentially expressed $(\mathrm{p}<0.001)$ in ccRCC versus normal kidney, 26 down-regulated and 9 up-regulated. The microRNA down-regulated in ccRCC were miR-100, miR-10b, miR-125b, miR26a+, miR-133b, miR-135a, miR-135b, miR-136, miR141, miR-149, miR-154, miR-199a, miR-200a, miR-200b, miR-200c, miR-204, miR-211, miR-218, miR-30a-3p, miR-30a-5p, miR-337, miR-411, miR-429, miR-507, miR510 , miR-514 and the microRNA up-regulated in ccRCC were miR-142-3p, miR-155, miR-185, miR-21, miR-210, miR-224, miR-34a, miR-34b, miR-592 (see Table 1), in agreement with recent studies $[12,14,15,65,66]$. The chro- 
Table 1: The 35 microRNA that distinguish tumor from normal tissue in human ccRCC.

\begin{tabular}{|c|c|c|c|}
\hline microRNA & Expression Status in ccRCC & $\begin{array}{l}\text { Hystotype (from references: } \\
[5-22,35-40,65,66,73,74,79])\end{array}$ & $\begin{array}{l}\text { Cancer-related Regions } \\
{[17,18]}\end{array}$ \\
\hline \multicolumn{4}{|l|}{ Name } \\
\hline \multirow[t]{2}{*}{ miR-100 } & Down & Up in pancreas, stomach & $11 q 23-q 24(D)$ \\
\hline & & Down in ovarian & \\
\hline miR-10b & Down & Down in breast & \\
\hline \multirow[t]{2}{*}{ miR-125b } & Down & Up in pancreas & $11 q 23(D)$ \\
\hline & & Down in breast & \\
\hline miR-26a+ & Down & Down in epithelial cancers & 3p21.3 (D) \\
\hline miR-133b & Down & Down in ovarian & \\
\hline miR-135a & Down & & $3 p 21.1-21.2(D)$ \\
\hline miR-135b & Down & & \\
\hline miR-136 & Down & & $14 q 32(D)$ \\
\hline miR-141 & Down & Up in lung, ovarian & \\
\hline miR-149 & Down & & $2 q 37(D)$ \\
\hline miR-154 & Down & Down in ovarian & $14 q 32(D)$ \\
\hline \multirow[t]{2}{*}{ miR-199a } & Down & Up in lung, pancreas, prostate & \\
\hline & & Down in ovarian & \\
\hline miR-200a* & Down & Up in ovarian & \\
\hline miR-200b & Down & Up in lung, ovarian & \\
\hline miR-200c & Down & Up in ovarian & \\
\hline miR-204 & Down & Down in ovarian & \\
\hline miR-211 & Down & & \\
\hline $\operatorname{miR}-218$ & Down & & $4 p 15.3(D)$ \\
\hline miR-30a-3p & Down & & \\
\hline
\end{tabular}


Table 1: The 35 microRNA that distinguish tumor from normal tissue in human ccRCC. (Continued)

\begin{tabular}{|c|c|c|c|}
\hline miR-30a-5p & Down & Down in lung & \\
\hline $\operatorname{miR}-337$ & Down & & $14 q 32(D)$ \\
\hline miR-377 & Down & & \\
\hline $\operatorname{miR}-411$ & Down & & $14 q 32(D)$ \\
\hline miR-429 & Down & & \\
\hline miR-507 & Down & & \\
\hline $\operatorname{miR}-510$ & Down & & \\
\hline $\operatorname{miR}-514$ & Down & & \\
\hline miR-142-3p & Up & & \\
\hline miR-155 & Up & Up in breast, colon, lung & $21 q 21(A)$ \\
\hline miR-185 & Up & Up in kidney, bladder & \\
\hline $\operatorname{miR}-21$ & Up & $\begin{array}{l}\text { Up in breast, colon, lung, } \\
\text { pancreas, prostate, stomach,; } \\
\text { gliobastoma cervical }\end{array}$ & $17 q 23.2(A)$ \\
\hline $\operatorname{miR}-210$ & Up & Up in breast & \\
\hline $\operatorname{miR}-224$ & Up & Down in lung, ovarian & $\mathrm{Xq} 28$ \\
\hline \multirow[t]{2}{*}{ miR-34a } & Up & Up in lung, rat RCC & $11 q 23-q 24(D)$ \\
\hline & & Down in neuroblastoma & \\
\hline miR-34b & Up & & \\
\hline miR-592 & Up & & \\
\hline
\end{tabular}

mosomal location of these microRNA (Table 1) shows that several are proximal to fragile regions and regions commonly deleted in ccRCC $[17,18]$. Figure $1 \mathrm{~A}$ shows a heat-map of the microRNA expression levels for samples in the primary dataset showing that they can robustly separate ccRCC from normal kidney.

\section{Step 2: mRNA differentially expressed in ccRCC versus normal kidney tissue}

Using SAM http://www-stat.stanford.edu/ tibs/SAM/ at $\mathrm{FDR}=0.1$ and 100 permutation tests, $2632 \mathrm{mRNA}$ probes were found up-regulated and 2238 were found down-regulated in ccRCC. The genes represented by these probes included many genes known to be dysregulated in ccRCC $[63,64]$. We saw significant upregulation of oncogenes VEGFA (vascular endothelial growth factor) and EGFR (epithelial growth factor receptor), integrin-mediated cell adhesion pathway genes (ITGA3, IGA5, ITGAM, ITGAX, ITGAL and CAV1), cell adhesion related genes (FN1, COL4A and LAMA4) and cytokines (GBP2 and GBP5). Similarly we noted down-regulation of tumor suppressor genes (VHL, SFRP1, CDKN1C and S100A2) and of mem- 


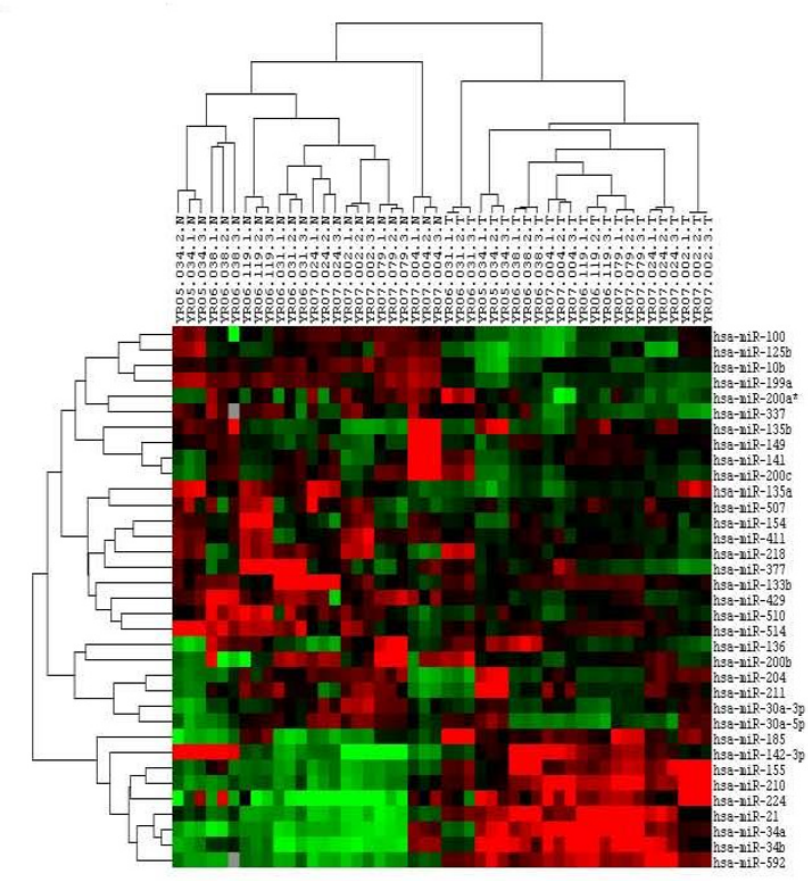

A

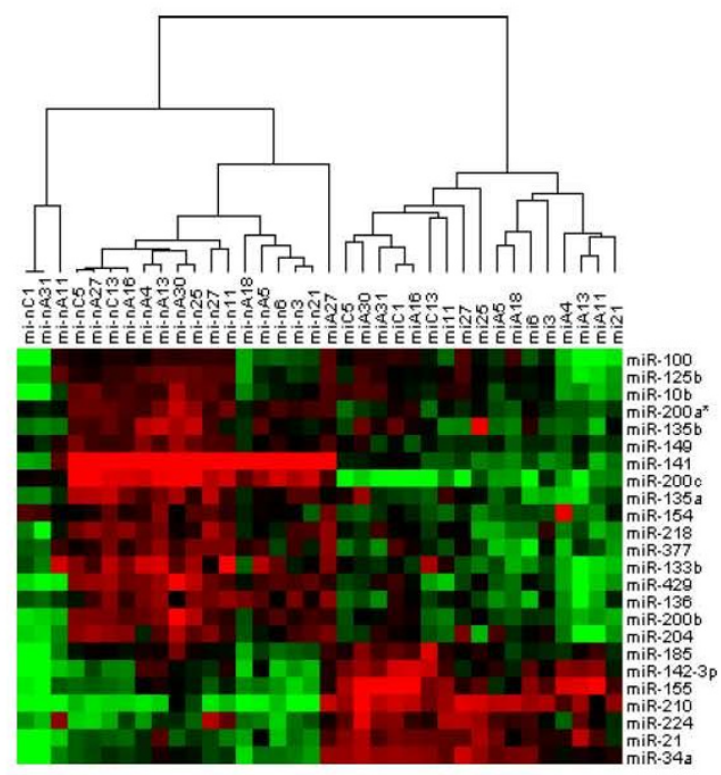

C

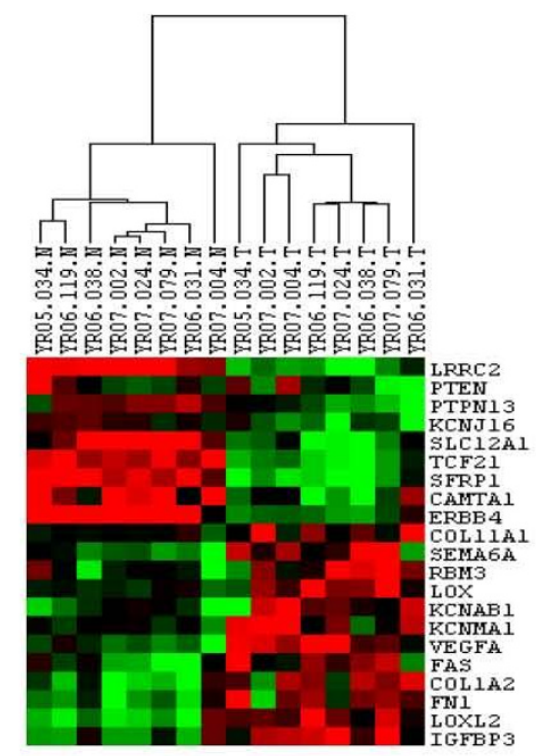

B

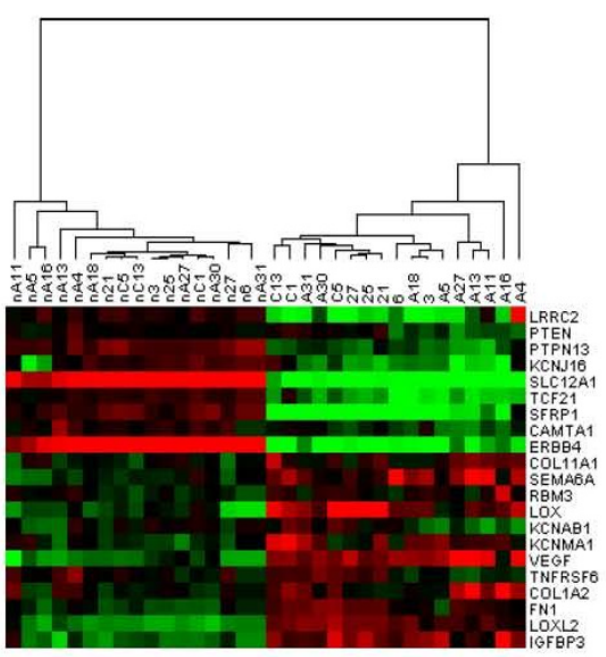

D

Figure 1 Differential expression of microRNA and mRNA between normal and tumor tissue. A. Heatmap of 35 microRNA differentially expressed in ccRCC and matched normal kidney tissue in the primary dataset. B. Heatmap of some of the identified mRNA targets of the microRNA in A as identified by our method. C. Heatmap of the 27 microRNA in A which were available on the Agilent chipset used on the validation samples. D. Validation sample set heatmap of mRNA levels for the same genes as in B. 
bers of the metallothionein family (MT2A, MT1E, MT1F, MT1G, MT1H, MT1M, MT1X).

\section{Steps 3 and 4: Identifying direct mRNA targets of dysregulated microRNA}

Pearson correlation analysis with $\mathrm{P}_{0}=-0.95$ was applied to each of the 35 differentially expressed microRNA and its putative mRNA targets (those with conserved seed sequences in their $3^{\prime} U T R$ as found in TargetScan). This procedure identified 11 mRNA targets for the 9 up-regulated microRNA. This list included several important tumor suppressor genes, such as PTEN, ERBB4 and SFRP1, known to be mutated or down-regulated in many tumors, including ccRCC $[16,17,23]$. The 26 down-regulated microRNA had 170 direct up-regulated mRNA targets, including oncogenes VEGFA, LOX, LOXL2 and FAS, well known to be involved in kidney cancer $[16,17,23]$.

The nine most significantly down-regulated and twelve most significantly up-regulated mRNA are listed in Table 2 and their heatmap is shown in Figure 1B. In Figure 2 we plot microRNA and mRNA levels for miR-200c and its target VEGFA. Note that the levels of miR-200c and its target VEGFA are not only anti-correlated overall, but are also anti-correlated separately in both ccRCC and normal tissue. Additional Files 1 and 2 contain the full list of microRNA/mRNA regulations identified by our analysis.

\section{Validation on a cohort of ccRCC/normal kidney samples}

\section{A. Validation of differentially expressed microRNA and mRNA}

Seventeen validation samples were collected from a new cohort of patients and analyzed by microRNA and mRNA profiling on Agilent arrays (see the Methods Section). Figure $1 \mathrm{C}$ shows a heat map of twenty-seven microRNA (those which were found on the Agilent chip) of the thirty five differentially expressed microRNA identified previously. A weighted voting classifier on binarized microRNA expression data in the validation set had $100 \%$ accuracy in leave-one-out (LOO) cross validation in distinguishing ccRCC from normal kidney. Figure 1D shows a heatmap of mRNA expression levels for the genes in Figure 1B. These were also found to be 100\% accurate at discriminating ccRCC from normal kidney using weighted voting and $\mathrm{LOO}$ cross validation analysis.

mRNA levels of three genes (ERBB4, SFRP1, SLC12A1) which were down-regulated in ccRCC and one gene (VEGFA) up-regulated in ccRCC were also measured by quantitative RT-PCR in twelve of the test samples. The results, shown in Figure 3A, demonstrate that mRNA levels of ERBB4, SFRP1, SLC12A1 and VEGFA were quantitatively and significantly down/up-regulated as expected.

\section{B. Validation of anti-correlation signature between some identified microRNA/mRNA pairs}

In Figure 3B-E, we plot the qRT-PCR expression levels of ERBB4, SFRP1, SLC12A1 and VEGFA versus Agilent chip measured levels of their regulatory microRNA (miR-224, miR-34a, miR-21 and miR-200c) for the twelve samples of Figure 3A. The overall strong anti-correlation signature between microRNA and mRNA levels is clearly visible in these plots. Figure 4 summarizes our validation analysis of a number of anti-correlation measurements between several identified microRNA/mRNA pairs in the Agilent chip data. The measured correlations between predicted microRNA/mRNA pairs are shown in the figure. Because of the higher level of noise in the Agilent chip data compared to QRT-PCR, we cannot apply the strict criterion $\left(P_{0}=-0.95\right)$ used in the primary dataset. Instead, the significance of the correlation (also shown) was computed using permutation tests as follows: A large number of datasets were obtained by permuting the sample labels in the microRNA or mRNA measurements. For each microRNA/mRNA pair, these permuted datasets were used to compute the null distribution for $\mathrm{P}$ and the significance of the measured value of $P$ was estimated in this null distribution. As the p-values in Figure 4 indicate, we validate a strong anti-correlation signature between mRNA levels of (KCNMA1, LOX), VEGF, SEMA6A, (LRRC2, PTPN13), SFRP1, ERBB4, SLC12A1 and TCF21, and their identified regulators: miR-149, miR-200c, mir141, miR-142-3p, miR-185, mir-34a, miR-224 and miR-21 respectively.

\section{In vitro validation of SEMA6A as a target of miR-141 in an RCC cell line}

Finally, to establish that this method can accurately predict functional and direct microRNA/mRNA regulation, we performed an in vitro analysis of one microRNA (miR-141), and its identified direct target SEMA6A. The RCC cell line CRL-1611 was transfected (by either Fugene or HyFect methods) with either pre-miR-141 or a control pre-miR, and levels of SEMA6A were measured on the case/control cell lines by semi-quantitative RTPCR. The results (Figure 5) showed that introduction of pre-miR-141 produced a significant reduction in the level of SEMA6A mRNA, validating SEMA6A as a functional and direct target of miR-141.

\section{Discussion}

We have developed and validated a simple method to identify direct functional mRNA targets of microRNA in ccRCC using patient matched tumor/normal samples. The method looks for the subset of anti-correlated microRNA/mRNA pairs from a larger set of microRNA 
Table 2: Some representative, direct mRNA targets of microRNA predicted by our method.

\begin{tabular}{|c|c|c|}
\hline microRNA & mRNA & Status of mRNA in ccRCC \\
\hline miR-142-3p & LRRC2 & Down ${ }^{+}$ \\
\hline miR-185 & PTEN & Down \\
\hline miR-185 & PTPN13 & Down ${ }^{+}$ \\
\hline miR-185 & KCNJ16 & Down \\
\hline $\operatorname{miR}-21$ & $\mathrm{SLC} 12 \mathrm{~A} 1$ & Down ${ }^{+}$ \\
\hline $\operatorname{miR}-21$ & TCF21 & Down ${ }^{+}$ \\
\hline miR-34a & SFRP1 & Down ${ }^{+}$ \\
\hline miR-34a & CAMTA1 & Down \\
\hline $\operatorname{miR}-224$ & ERBB4 & Down ${ }^{+}$ \\
\hline miR-199a & COL11A1 & Up \\
\hline miR-141/200a* & SEMA6A & $\mathrm{Up}^{+}$ \\
\hline $\operatorname{miR}-141 / 200 a^{*}$ & RBM3 & Up \\
\hline miR-149 & LOX & $\mathrm{Up}^{+}$ \\
\hline miR-149 & KCNAB1 & $\mathrm{Up}^{+}$ \\
\hline miR-149 & KCNMA1 & $\mathrm{Up}^{+}$ \\
\hline $\mathrm{miR}-200 \mathrm{bc} / 429$ & VEGF & $\mathrm{Up}^{+}$ \\
\hline $\mathrm{miR}-200 \mathrm{bc} / 429$ & FAS & Up \\
\hline $\mathrm{miR}-204 / 211$ & COL1A2 & Up \\
\hline $\mathrm{miR}-204 / 211$ & FN1 & Up \\
\hline $\operatorname{miR}-218$ & LOXL2 & Up \\
\hline $\operatorname{miR}-218$ & IGFBP3 & Up \\
\hline
\end{tabular}

The full list of identified microRNA/mRNA pairs is given in Additional Files 1 and $2 .{ }^{+}$marks microRNA/mRNA anti-correlations that were tested/validated on an independent set of matched ccRCC/normal kidney samples. 


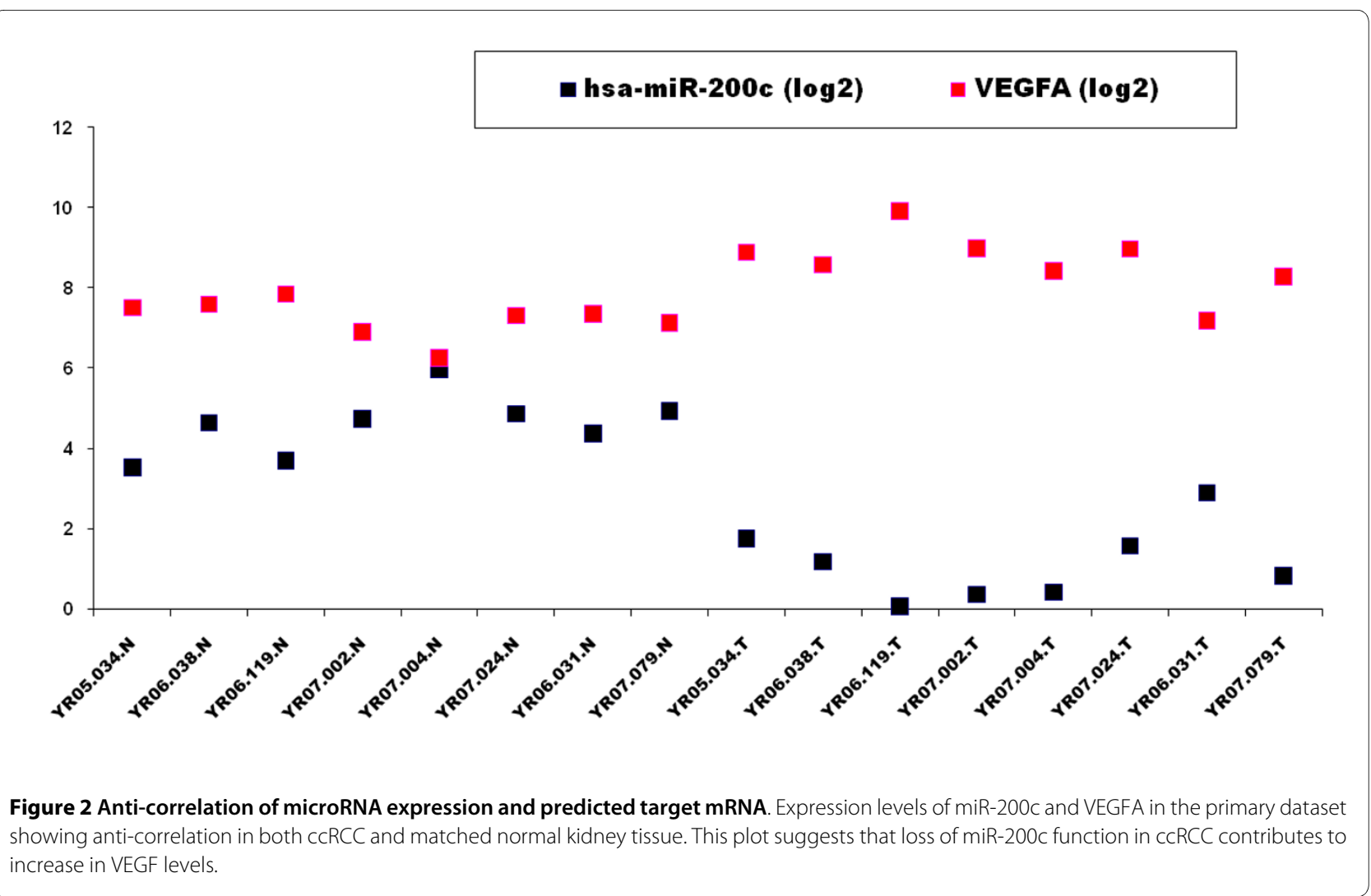

and mRNA able to distinguish tumor from normal tissue, with the additional requirement of a highly conserved seed sequences for the corresponding microRNA in the 3'UTR of the corresponding gene. Our method can not only identify microRNA/mRNA pairs which discriminate normal from cancer tissue, but also dysregulated regulation mechanisms between them that may initiate and/or drive the disease process.

We used an RT-PCR panel for our initial discovery experiments and microRNA and microarray chips both for validation of our previously discovered microRNA/ mRNA pairings and to expand the available pool of microRNAs to all currently known microRNAs for a comprehensive examination of microRNA/mRNA pairs. In comparing the two data modalities, we noticed that in the RT-PCR data, the sample to sample variation in the normal samples (i.e. the population variation) was comparable to the change in level between normal and tumor (in the same patient) which caused a statistically significant up/down regulation of the target mRNA. To find reliable matches, it was therefore crucial to minimize stochastic error. We observed that the RT-PCR data had lower stochastic variance than the microarray data (estimated using replicate measurements in the RT-PCR analysis and from bootstrap analysis of the microarray data). This noise effect is also reflected in the measured P0 values in the validation analysis on the microarray data (Fig- ure 4), which are smaller in magnitude (|P0| 0.5-0.6) than the strict cutoff $|\mathrm{PO}|>0.95$ used in the discovery phase on the RT-PCR data. Since the present study is mainly to demonstrate "proof of concept", we limited the RT-PCR data for discovery and the microarray data for validation. In a more extensive study, with sufficiently large sample sizes and more accurate data from high throughput technologies (microarrays, sequencing) it may be feasible and cost effective to use a high throughput platform for discovery and RT-PCR for validation. Such an analysis might also identify a much bigger set of microRNA/mRNA relationships. Although our method is very robust, as described, it cannot find all mRNA targets. Its principal merit is the ability to reduce the large number of relatively speculative matches from seed sequences alone to a smaller set of functional, tissue specific targets. While this smaller set is perhaps incomplete, it is more reliable. Additionally, the use of perfect seed sequence matches can easily be relaxed. A more serious issue is that the method as described cannot find targets affected by translation inhibition. For such targets, the changes in microRNA levels would leave mRNA levels unaffected, but reduce protein levels. Such targets might be identified if protein levels in tumor/normal samples were also measured along with the microRNA and mRNA levels. The method could then be adapted to identify targets affected by translation inhibition by using an 

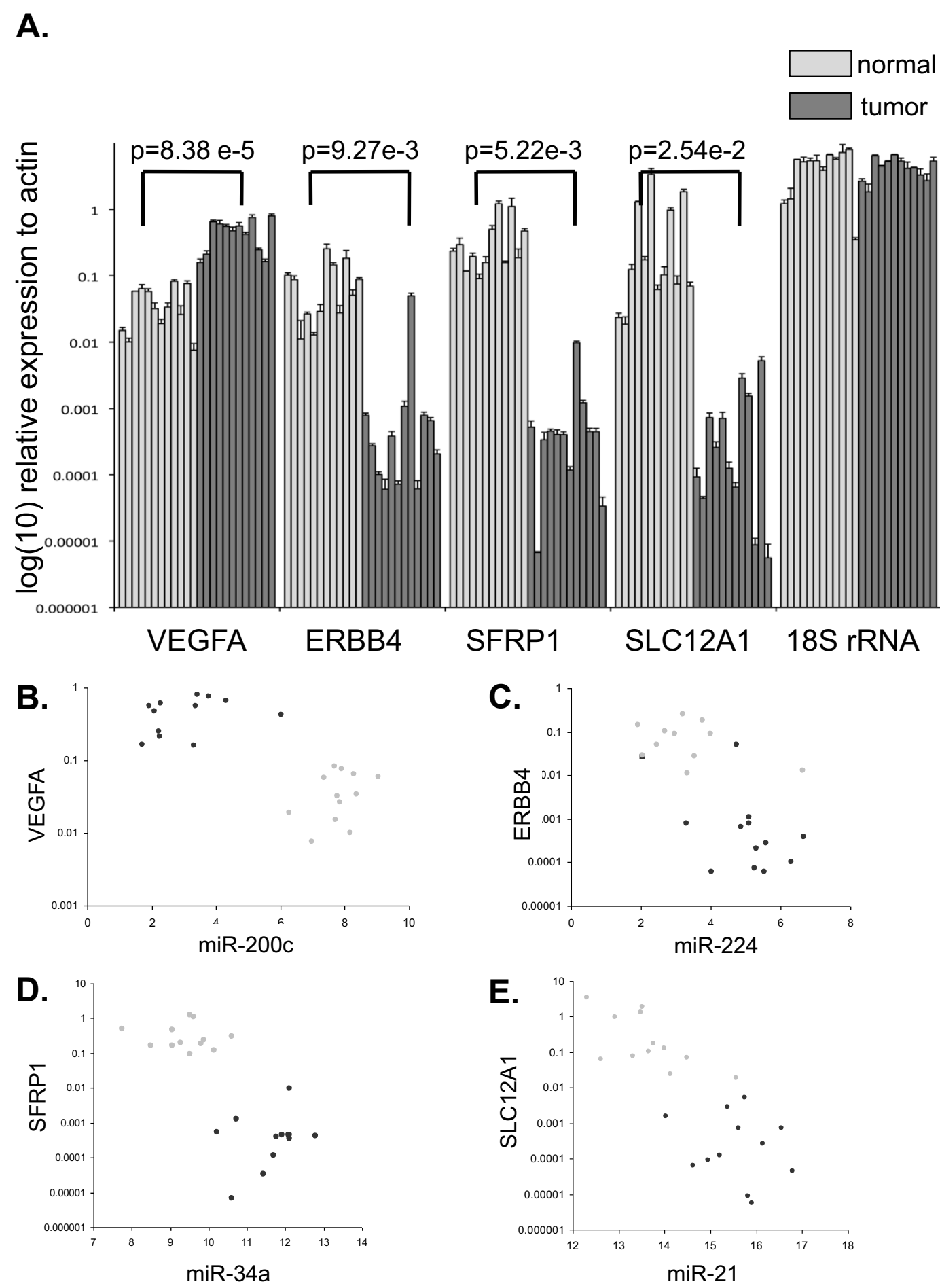

Figure 3 qRT-PCR validation of predicted mRNA targets of microRNA. A. qRT-PCR measured mRNA levels of VEGF, ERBB4, SFRP1, and SLC12A1 in 12 ccRCC and matching normal kidney tissue in the validation set. Expression levels, including those of $18 \mathrm{~S}$ rRNA (control) are plotted on a log-scale relative to a housekeeping gene (beta-actin). These expression level changes agree with predicted changes based on the primary dataset. Dark grey bars denote tumors, while light grey bars denote normal kidney tissue. p-values are for accuracy of discrimination of ccRCC/normal kidney using the t-test. B-E. Agilent chip expression levels of miR-200c, miR-244, miR-34a and miR-21 versus the levels of mRNA that they regulate: VEGFA, ERBB4, SFRP1 and SLC12A1 respectively as measured by qRT-PCR for 12 validation set samples The dark circles represent the values in ccRCC and the light circles in normal kidney. It is clear that loss of mir-200c regulation contributes to an increase in VEGFA transcript while for the other three (tumor suppressor genes), the level of transcript decreases because of a gain in the level of the corresponding microRNA. 


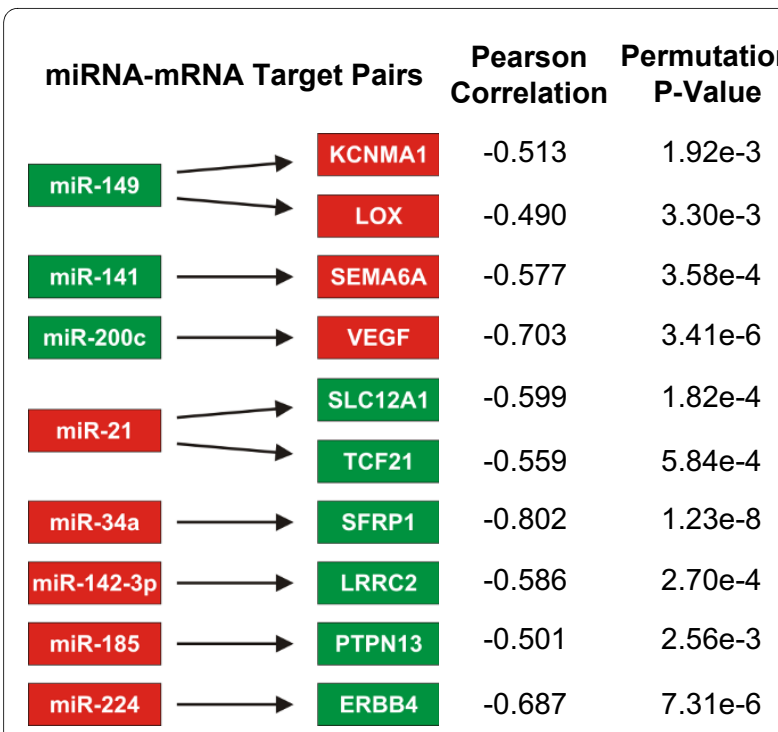

Figure 4 Validation of microRNA/mRNA regulation relationships in Table 2. Red/green boxes represent over/under expression of microRNA or mRNA levels in ccRCC compared to normal kidney. Pearson correlations were calculated for mRNA and microRNA expression values for tumor and normal combined and are shown with their p-values for significance using the permutation test.

appropriate joint correlation/anti-correlation analysis of microRNA/mRNA/protein levels. Our method, as described here, would also miss regulation that proceeds via intermediate states. In these cases, there would be no seed sequence match (exact or approximate) between a microRNA and the mRNA whose level was affected by it. We could attempt to identify such secondary effects by

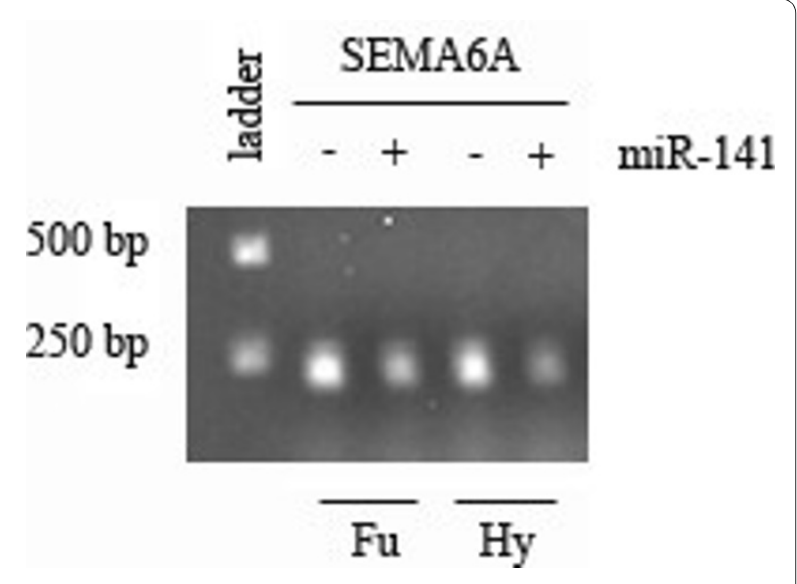

Figure 5 Validation of a Direct interaction between miR-141 and SEMA6A. Results of in-vitro experiment on RCC cell line CRL-1611 transfected either with pre-miR-141 or a control pre-miR using either Fugene (Fu) or Hyfect (Hy). RNA was extracted after 48 hours and the expression of SEMA6A was measured using semi-quantitative RT-PCR. There is clear reduction in mRNA of SEMA6A upon introduction of miR141 by either transfection method in these cells. eliminating the seed sequence match requirement but keeping the requirement of a high correlation/anti-correlation signal between microRNA/mRNA levels. Whether such a procedure would work would depend on the degree to which the intermediate state gene/protein is affected and measurable. We briefly discuss some of these issues below. However, it should be noted that these studies would require significantly larger sample sizes and are beyond the scope of the present paper. The next round of TCGA http://cancergenome.nih.gov/ may make these types of analyses more feasible.

Although here, we focused on microRNA/mRNA pairs with exact seed sequence match and an anti-correlation signal in both tumor and normal samples, as noted above, with additional samples it should be possible to use this method and simple extensions to identify more subtle types of dysregulation. For example, if a mutation in a microRNA in the tumor samples causes loss of its function (failure to regulate its target mRNA), then although the microRNA/mRNA levels would be anti-correlated in normal tissue, they would not be anti-correlated in tumor samples. Similarly a de-novo gain of microRNA function would be signaled by an anti-correlated signal in tumor samples which was absent in the normal samples.

In our data, we did observe several correlations and anti-correlations between microRNA/mRNA pairs in tumor or normal samples without a corresponding seed sequence match. As noted above, these most likely represent regulations which proceed via intermediate states and hence cannot be identified by seed sequence matches. For example, if increased levels of microRNA X down-regulates expression of a protein which is a transcriptional repressor of gene $\mathrm{Y}$, there will be a strong correlation between $\mathrm{X}$ and $\mathrm{Y}$ levels but no seed sequence match. Conversely, if microRNA $X$ regulates a protein which is a transcription factor for gene $Y$ then the levels of $\mathrm{X}$ and $\mathrm{Y}$ will be anti-correlated without a seed sequence match. The measurement of such correlations would extend the network of microRNA control beyond first level regulators but would require significant increases in the number of samples $(\sim 100-200)$ for statistical significance.

Since the method finds functional relationships, it should be useful for identifying pharmaceutically relevant mechanisms which suggest drug targets for therapy. We describe below some of the regulations we identified which have pharmaceutical relevance.

\section{microRNA which shut down multiple tumor suppressor genes in cCRCC}

We found several dysregulated microRNA which targeted multiple tumor suppressor genes. For example, the oncogenic miR-185 was significantly up-regulated in ccRCC and anti-correlated with the tumor suppressor gene 
PTEN, suggesting that its gain of function shuts down PTEN in ccRCC. Mutated or down-regulated in many advanced cancers [67], PTEN loss activates the PI3KAKT [68] signaling pathway and its downstream target mTOR, with important implications in RCC development and therapeutic selection $[59,60,69,70]$. Another identified target of miR-185 was PTPN13 (also a predicted miR-185 target in miRBase: http://microrna.sanger.ac.uk/ ), which is a Fas-associated protein tyrosine phosphatase and putative tumor suppressor gene that can inhibit PI3K/AKT signaling, suppress the influence of insulinlike growth factor-I on cell survival and induce apoptosis [71]. KCNJ16, member of the potassium channel subfamily of membrane proteins, was also identified as a target of miR-185. Such membrane proteins have been suggested in anti-cancer therapies because of their important role in cell growth [72] and are known to be down-regulated in RCC [73].

miR-34a is known to be over-expressed in various tumors and associated with cell proliferation [74]. In our data, it was up-regulated in ccRCC and predicted to target SFRP1, a known regulator of the Wnt signaling pathway and a tumor suppressor gene whose loss has been observed in a majority of RCC patients [75]. Another tumor suppressor regulated by miR-34a was CAMTA1 [76], a reduction in whose levels correlates with poor outcome in neuroblastoma [77]. Finally, we find miR-224, associated with a human chromosome fragile site on Chr$\mathrm{Xq} 28$ [18], is up-regulated in ccRCC and predicted to target ERBB4, a member of the EGFR family, a potential tumor suppressor known to be strongly down-regulated in $\mathrm{CCRCC}$ [78].

\section{Hypoxia induced microRNAs}

A hypoxic tumor microenvironment can directly activate the expression of several microRNA $[79,80]$. For example, miR-21, miR-210 and miR-155 reduce pro-apoptotic signaling in response to a hypoxic environment and are consistently over-expressed in a variety of human tumors (Table 1). ccRCC is a unique setting in which to study these microRNAs, given that $V H L$ loss constitutively stabilizes one or more HIF factors, thereby creating a pseudo-hypoxic scenario in ccRCC tumor cells $[59,60]$. We found that hypoxia related microRNA had the most significant fold changes, with miR-210, miR-155 and miR-21 being amongst the top., suggesting a major role for them in renal carcinogenesis. We found 16 genes down-regulated in tumor, inversely correlated with miR21 and enriched (via KEGG) in the cell adhesion (CAM) pathway at $p=0.0006$. Loss of CAM degrades the intra and extracellular matrix, leading to abnormal cell growth patterns. Among these 16 genes, two were identified as direct targets of miR-21: SLC12A1 and TCF21, both of which have been reported down-regulated in ccRCC $[69,70]$.

\section{Identification of microRNA family interactions}

We found evidence that families of microRNAs may be coordinately participating in microRNA/mRNA interactions. One example in ccRCC is the miR-204/211 family, which was significantly down-regulated in ccRCC samples. We identified thirty five significant mRNA targets $(p$ $=0.0001$ ) for this family (Additional File 2). Among these, eight were on Chromosome 3q, a common amplicon region in many epithelial tumors [81]. These genes include C3orf58, CCDC50, DTX3L, PLD1, TRIM59, two oncogenes ECT2 and RAP2B, and a hypoxia associated protein SERP1 [82]. The gain of this chromosome arm was previously associated with papillary RCCs [83], and our observation in clear cell RCC implies a possible regulatory relation between $\mathrm{miR}-204 / 211$ and the genes in this region as an alternate mechanism of up-regulation of this group of genes.

Another example is the miR-200 family which includes two microRNA clusters, one on Chromosome 1p36.3 (miR-200a*/200b/429) and another on Chromosome 12p13 (miR-200c/141). Five miR-200 family members contain very similar seed sequences - AAUACU for miR200b/200c/429 and AACACU for miR-200a*/141 [84]. Recently, several other groups have reported a role for the miR-200 family in the Epithelial-Mesenchymal-transition (EMT) and in cancer cell migration, the latter by directly targeting the transcription factors ZEB1 and ZEB2, which regulate E-Cadherin, a mediator of cell-cell adhesion $[84,85]$. Another study [86] identified a regulatory loop between these microRNAs and ZEB transcription factors as well as the EMT inducer TGF $\beta$. In epithelial cells, miR200 family microRNAs and E-cadherin maintain higher level expression by repressing ZEB1, ZEB2 and TGF $\beta$; on the other hand, in mesenchymal cells and tumors, the upregulation of ZEB factors is triggered by TGF $\beta$ and suppresses the transcription of miR-141/200c by binding to their putative common promoter region. In our primary dataset, ZEB1 and ZEB2 were both up-regulated in six out of our eight ccRCC samples and, their expression levels were highly anti-correlated with the miR-200 family in both tumor and normal samples. As confirmation of these results, down-regulation of miR-141 and miR-200c and their function on ZEB2 in ccRCC has recently been reported [87]. We also noted that in our data, the anticorrelation between VEGFA and the miR-200 family was strongest in normal kidney tissue, suggesting that loss of this regulation may be an important factor providing a permissive environment for HIF transcriptional signaling. Our hypothesis (prediction) from these various observations is that in normal kidney, the expression level of HIF $2 \alpha$ and its downstream targets (VEGFA, TGF $\beta$ etc) 
are regulated by miR-141, 200a*, 200b and 200c and the loss of this microRNA regulation, in concert with VHL loss, is responsible for activation of the HIF pathway.

One intriguing association which we have identified (miR-141 regulation of SEMA6A) is highly significant for therapy in ccRCC. This is because the soluble extracellular domain of SEMA6A has been engineered to effectively inhibit VEGF-mediated tumor formation [88]. Hence, our results imply that miR-141 may have a role in gene therapy. A model which summarizes our observations and integrates it with mechanisms for ccRCC dysregulation from the literature is shown in Figure 6. This model integrates our measured microRNA regulatory mechanisms with known transcriptional activity resulting from $V H L$ loss and activation of the hypoxia response pathway. The pathways shown in Figure 6 are likely highly interconnecting, and this model, and the individual functional interactions it suggests, need to be validated (and probably significantly extended) by direct experimental targeting of microRNA levels and measurements of each of the predicted target genes in a larger cohort (such as is planned for The Cancer Genome Atlas (TCGA) in its next phase).

\section{Conclusions}

The main innovation in this paper is the use of an anticorrelation analysis of microRNA/mRNA levels in two cell types from the same patient (tumor/normal cells in our case) to identify functional mRNA targets of altered microRNA. The method can obviously extend to any tissue type and might be useful in other contexts: for instance, by using microdissection to harvest cells from different cellular compartments from the same breast cancer patient, it might reveal the microRNA/mRNA regulation program which causes progression of normal epithelium to hyperplasia to DCIS to invasive disease. The method might also be useful in non-cancer studies, such as in identifying the role of microRNA and their target genes in the transition from stem cells to differentiated cells or in embryogenesis. In summary, in this paper, we

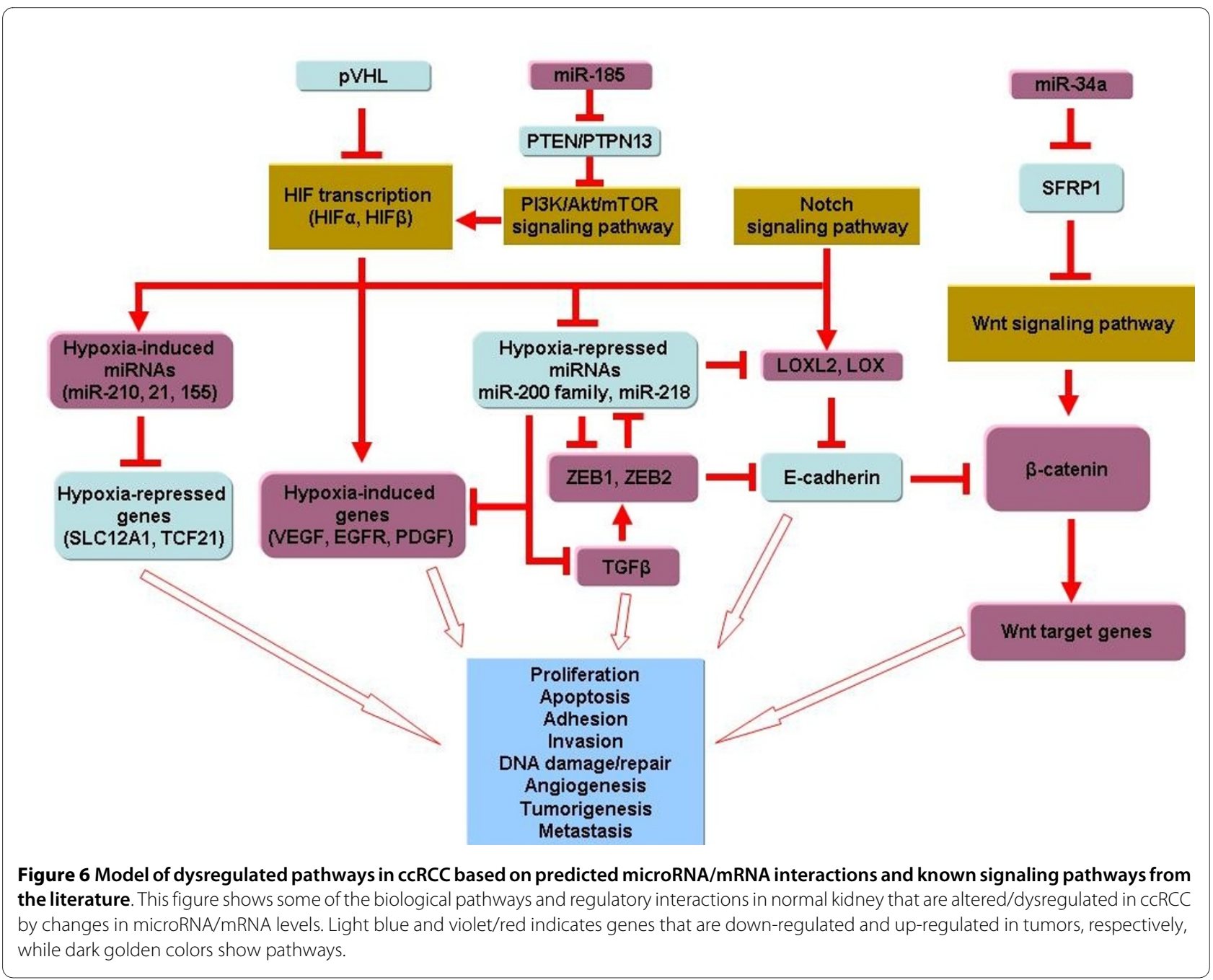


have demonstrated a simple method to identify tissue specific mRNA targets of microRNA, which is expandable to many study types.

\section{Methods \\ Primary Dataset: Tissue specimens, RNA extraction and cDNA synthesis}

Eight ccRCC tissue specimens and adjacent normal kidney (NK) tissue were collected from patients at Boston Medical Center and Cleveland Clinic immediately after radical nephrectomy, processed and stored at $-80^{\circ} \mathrm{C}$ until RNA extraction. Total RNA was extracted by homogenizing 40 milligrams of frozen tissue, followed by RNA isolation. The concentration of the purified RNA was assessed and RNA was reverse transcribed into first-strand cDNA for real-time PCR.

\section{Identifying the microRNA panel}

Using this primary cohort of eight normal/tumor tissue pairs, microRNA expression profiling was performed in triplicate for each normal and ccRCC sample using quantitative real-time PCR in a 384-well format (System Biosciences (SBI), Mountain View, CA, USA). Expression levels were quantified using the comparative Ct (cycle threshold) method and normalized to a "housekeeping" microRNA, identified as the one whose level was most unchanged across normal and tumor samples. To identify microRNA signatures that distinguish tumor from normal tissue, we used the signal-to-noise ratio statistic [89] and computed the associated $p$-value using 1000 permutation tests with multiple hypothesis correction using false discovery rate (FDR) and $q$-values [90].

\section{Identifying differentially expressed mRNA}

mRNA expression levels for the primary paired tumor/ normal specimens were measured by hybridizing extracted RNA to Affymetrix HG-U133 Plus 2.0 arrays, and the expression data was exported by MAS5.0 and $\log _{2}$ transformed. To identify genes which strongly differentiate between ccRCC and normal kidney tissue, we use a two-fold expression cutoff and assessed their significance using permutation tests to measure $p$-values and False Discovery Rates (FDR) using SAM http://wwwstat.stanford.edu/ tibs/SAM/.

\section{Validation on patient matched ccRCC and normal kidney}

The validation cohort of $17 \mathrm{ccRCC}$ tumor and adjacent normal kidney tissue samples was collected from the University of North Carolina Tumor Bank. These samples were snap frozen in liquid nitrogen, quality assured by histologic analysis of adjacent fixed sections, and stored at -80. Total RNA was extracted using the Qiagen miRNeasy Mini Kit, quantified by Nanodrop (ThermoScientific), and quality checked on an ABI Bioanalyzer
(ABI). MicroRNA analysis on the validation set of 17 ccRCC tumor and surrounding NK was performed using a highly distinct platform from the experimental set: Samples were end-labeled and hybridized to a commercial densely tiled probe Agilent $8 \times 15 \mathrm{~K}$ microRNA array. We included more samples in the validation set than in the primary set because of the lower signal/noise ratio in microRNA expression values using the Agilent chip compared to RT-PCR. The validation set of mRNA samples were co-hybridized with a commercial RNA reference (Stratagene) supplemented with a routine set of tumor genes [83] to provide a standard reference for relative expression. Hybridization was done on a commercial Agilent human $4 \times 44 \mathrm{~K} \mathrm{cDNA}$ array to measure expression levels.

The samples collected at Boston University and Cleveland Clinic were obtained from patients immediately after radical nephrectomy under IRB approved informed consent from all patients. The IRB approving bodies were the Boston University Medical Center Institutional Review Board and the Cleveland Clinic Regional Institutional Review Board respectively. The samples collected at the University of North Carolina Medical School were collected as a tumor banking protocol entitled Procurement of Solid Tumor Tissue (LCCC 9001) approved by the Biomedical Investigational Review Board (IRB) at the University of North Carolina Medical School.

\section{Validation set ccRCC mRNA measurements using quantitative RT-PCR}

Total RNA from a subset of 12 of the 17 validation tumors and matched normal kidney sample pairs was also analyzed for mRNA expression of the predicted target genes VEGFA, ERBB4, SFRP1, and SLC12A1. Briefly, cDNA was prepared from $500 \mathrm{ng}$ of RNA using SuperScript II polymerase, using manufacturer recommended standard buffer and temperature conditions. cDNA was analyzed by quantitative RT-PCR using commercial FAM-labeled probe sets (ABI) using standard cycle conditions. For each set of cDNAs analyzed, control $18 \mathrm{~S}$ ribosomal subunit and beta-actin cDNA were measured for internal normal controls. Cycle threshold values were corrected by normalization to actin.

\section{In vitro validation of SEMA6A as a target of miR-141}

Human renal cell adenocarcinoma cells (ATCC, CRL1611) were transfected with either the negative control pre-miR or hsa-miR-141 (Ambion) using either FuGENE HD (Roche) or HyFect (Denville scientific) transfection reagents. RNA was isolated after 48 hours using the Trizol reagent (Invitrogen) and treated with DNase. cDNA was synthesized using the SuperScript III First-Strand synthesis system for RT-PCR (Invitrogen) using oligo(dT) primers according to the manufacturer's instructions. 
PCR was performed using GeneAmp Fast PCR master mix (Applied Biosystems) using SEMA6A primers (Sigma) for 35 cycles. The specific primers used were: SEMA6A forward: 5'-CCTGGACACCAGTTCCTGAT SEMA6A reverse: 5'-GCAATTTTGGTAAGGCGGTA. The samples were analyzed on $1.5 \%$ agarose gel.

\section{Additional material}

Additional file 1 Targets of upregulated microRNA: This file contains the list of mRNA targets of upregulated microRNAs in cCRCC compared to normal kidney as identified by our method.

Additional file $\mathbf{2}$ Targets of downregulated microRNA: This file contains the list of mRNA targets of downregulated microRNAs in cCRCC compared to normal kidney as identified by our method.

\section{Authors' contributions}

The ideas for the study were developed and implemented in the labs of GB and WKR by HL, ARB and AR. The manuscript was written by HL, ARB, AR, WKR and GB. AJL provided guidance and background on the biology. The transfection assay was done in the lab of SG by YM and JO. The primary dataset was generated by $D J$ in the lab of LL. The validation data and lab analysis was done by ARB in the lab of WKR with significant assistance from AA. The bioinformatic analyses were carried out mainly by $\mathrm{HL}$ with significant help of $A R B, A R, G A$ and MS. The required software was developed by MS. All authors have read and approved the final manuscript.

\section{Acknowledgements}

The research of GB is partly funded by grants from the Cancer Institute of New Jersey and the New Jersey Commission for Cancer Research. GB thanks the Kavli Institute at the University of California, Santa Barbara for their hospitality while this work was initiated. WKR acknowledges support of the Lineberger Comprehensive Cancer Center Tissue Procurement and Genomics Core Facility and the Crawford Fund for support of kidney cancer research.

\section{Author Details}

1BioMaPS Institute, Rutgers University, Piscataway, NJ 08854, USA, 2 Lineberger Comprehensive Cancer Center, University of North Carolina, Chapel Hill, NC 27599, USA, ${ }^{3}$ Broad Institute of MIT and Harvard, 7 Cambridge Center, MA, 02142, USA, ${ }^{4}$ Cancer Institute of New Jersey, Robert Wood Johnson Medical School, New Brunswick, NJ 08903, USA, 5Department of Pathology, Boston University Medical School, Boston, MA 02118, USA, ${ }^{6}$ Cambridge Health Alliance, Harvard Medical School, Cambridge MA 02139, USA, ${ }^{7}$ Simons Center for Systems Biology, Institute for Advanced Study, Princeton, NJ 08540, USA, 8Departments of Medicine and Genetics, University of North Carolina, Chapel Hill, NC 27599, USA, 9Department of Molecular Biology and Biochemistry, Rutgers University, Piscataway, NJ 08854, USA, ${ }^{10}$ Department of Physics, Rutgers University, Piscataway, NJ 08854, USA and ${ }^{11}$ Current address: Bioinformatics, Centocor R\&D Inc, 145 King of Prussia Road, Radnor, PA 19087, USA

Received: 12 November 2009 Accepted: 27 April 2010 Published: 27 April 2010

\section{References}

1. Chen K, Rajewsky N: The evolution of gene regulation by transcription factors and microRNAs. Nat Rev Genet 2007, 8:93-103.

2. He L, Hannon GJ: MicroRNAs: small RNAs with a big role in gene regulation. Nat Rev Genet 2004, 5(7):522-531.

3. Kim NV: MicroRNA biogenesis: coordinated cropping and dicing. Nat Rev Mol Cell Biol 2005, 6:376-385.

4. Pillai RS: MicroRNA function: multiple mechanisms for a tiny RNA? RNA 2005, 11(12):1753-1761.

5. Calin GA, Croce CM: MicroRNA signatures in human cancers. Nat Rev Cancer 2006, 6(11):857-866.

6. Volinia S, Calin GA, Liu CG, Ambs S, Cimmino A, Petrocca F, Visone R, lorio M, Roldo C, Ferracin M, Prueitt RL, Yanaihara N, Lanza G, Scarpa A, Vecchione A, Negrini M, Harris CC, Croce CM: A microRNA expression signature of human solid tumors defines cancer gene targets. Proc Natl Acad Sci USA 2006, 103(7):2257-2261

7. Esquela-Kerscher ASlack FJ: Oncomirs - microRNAs with a role in cancer. Nat Rev Can 2006, 6:259-269.

8. He L, He X, Lim LP, de Stanchina E, Xuan Z, Liang Y, Xue W, Zender L, Magnus J, Ridzon D, Jackson AL, Linsley PS, Chen C, Lowe SW, Cleary MA, Hannon GJ: A microRNA component of the p53 tumour suppressor network. Nature 2007, 447(7148):1130-1134.

9. Deng S, Calin GA, Croce CM, Coukos G, Zhang L: Mechanisms of microRNA deregulation in human cancer. Cell Cycle 2008, 7:2643-2646.

10. Lu J, Getz G, Miska EA, Alvarez-Saavedra E, Lamb J, Peck D, Sweet-Cordero A, Ebert BL, Mak RH, Ferrando AA, Downing JR, Jacks T, Horvitz HR, Golub TR: MicroRNA expression profiles classify human cancers. Nature 2005, 435:834-838.

11. Barad O, Meiri E, Avniel A, Aharonov R, Barzilai A, Bentwich I, Einav U, Gilad S, Hurban P, Karov Y, Lobenhofer EK, Sharon E, Shiboleth YM, Shtutman M, Bentwich Z, Einat P: MicroRNA expression detected by oligonucleotide microarrays: system establishment and expression profiling in human tissues. Genome Res 2004, 14:2486-2494

12. Gottardo F, Liu CG, Ferracin M, Calin GA, Fassan M, Bassi P, Sevignani C, Byrne D, Negrini M, Pagano F, Gomella LG, Croce CM, Baffa R: Micro-RNA profiling in kidney and bladder cancers. Urol Oncol 2007, 25(5):387-392.

13. Huang Y, Dai Y, Yang J, Chen T, Yin Y, Tang M, Hu C, Zhang L: Microarray analysis of microRNA expression in renal clear cell carcinoma. Eur J Surg Oncol 2009, 35(10):1119-1123.

14. Jung M, Mollenkopf HJ, Grimm C, Wagner I, Albrecht M, Waller T, Pilarsky C, Johannsen M, Stephan C, Lehrach H, Nietfeld W, Rudel T, Jung K, Kristiansen G: MicroRNA profiling of clear cell renal cell cancer identifies a robust signature to define renal malignancy. J Cell Mol Med 2009, 13(9B):3918-28.

15. Juan D, Alexe G, Antes T, Liu H, Madabhushi A, Delisi C, Ganesan S, Bhanot G, Liou L: MicroRNA Expression Profile in Clear-Cell Kidney Cancer. J Urology in press.

16. Chow TF, Youssef YM, Lianidou E, Romaschin AD, Honey RJ, Stewart R, Pace KT, Yousef GM: Differential expression profiling of microRNAs and their potential involvement in renal cell carcinoma pathogenesis. Clin Biochem 2009, 43(1-2):150-158.

17. Alimov A, Kost-Alimova M, Liu J, Li C, Bergerheim U, Imreh S, Klein G, Zabarovsky ER: Combined LOH/CGH analysis proves the existence of interstitial 3p deletions in renal cell carcinoma. Oncogene 2000, 19(11):1392-1399.

18. Calin GA, Sevignani C, Dumitru CD, Hyslop T, Noch E, Yendamuri S, Shimizu M, Rattan S, Bullrich F, Negrini M, Croce CM: Human microRNA genes are frequently located at fragile sites and genomic regions involved in cancers. Proc Natl Acad Sci USA 2004, 101(9):2999-3004

19. Ambs S, Prueitt RL, Yi M, Hudson RS, Howe TM, Petrocca F, Wallace TA, Liu CG, Volinia S, Calin GA, Yfantis HG, Stephens RM, Croce CM: Genomic profiling of microRNA and messenger RNA reveals deregulated microRNA expression in prostate cancer. Cancer Res 2008, 68(15):6162-6170.

20. Porkka KP, Pfeiffer MJ, Waltering KK, Vessella RL, Tammela TL, Visakorpi T: MicroRNA expression profiling in prostate cancer. Cancer Res 2007, 67:6130-6135

21. Lawrie CH, Gal S, Dunlop HM, Pushkaran B, Liggins AP, Pulford K, Banham AH, Pezzella F, Boultwood J, Wainscoat JS, Hatton CS, Harris AL: Detection of elevated levels of tumour-associated microRNAs in serum of patients with diffuse large B-cell lymphoma. Br J Haematol 2008, 141(5):672-675

22. Resnick KE, Alder H, Hagan JP, Richardson DL, Croce CM, Cohn DE: The detection of differentially expressed microRNAs from the serum of ovarian cancer patients using a novel real-time PCR platform. Gynecol Oncol 2009, 112:55-59.

23. Ljungberg B: Prognostic markers in renal cell carcinoma. Curr Opin Urol 2007, 17(5):303-308.

24. Kovalchuk O, Filkowski J, Meservy J, Innytskyy Y, Tryndyak VP, Chekhun VF, Pogribny IP: Involvement of microRNA-451 in resistance of the MCF-7 breast cancer cells to chemotherapeutic drug doxorubicin. Mol Cancer Ther 2008, 7(7):2152-2159.

25. Nahta R, Takahashi T, Ueno NT, Hung MC, Esteva FJ: P27kip1 downregulation is associated with trastuzumab resistance in breast cancer cells. Cancer Res 2004, 64(11):3981-3986. 
26. Dillhoff M, Liu J, Frankel W, Croce C, Bloomston M: MicroRNA-21 is overexpressed in pancreatic cancer and a potential predictor of survival. J Gastrointest Surg 2008, 12:2171-2176.

27. Slack FJ, Weidhaas JB: MicroRNA in cancer prognosis. N Engl J Med 2008, 359:2720-2722

28. Hurst DR, Edmonds MD, Scott GK, Benz CC, Vaidya KS, Welch DR: Breast cancer metastasis suppressor 1 up-regulates miR-146, Which suppresses breast cancer metastasis. Cancer Res 2009, 69(4):1279-1283.

29. Ng Enders KO, Chris LP Wong, SK Ma, Kwong A: MicroRNA as New Players for Diagnosis, Prognosis and Therapeutic Targets in Breast Cancer. J Oncology 2009, 2009:305420.

30. Barh D, Parida S, Parida BP, Viswanathan G: Let-7, miR-125, miR-205, and miR-296 are prospective therapeutic agents in breast cancer molecular medicine. Gene Ther and Mol Biol 2008, 12:189-206.

31. Iorio MV, Casalini P, Tagliabue E, Menard S, Croce CM: MicroRNA profiling as a tool to understand prognosis, therapy response and resistance in breast cancer. Eur J Cancer 2008, 44:2753-2759.

32. Corney DC, Nikitin AY: MicroRNA and ovarian cancer. Histol Histopathol 2008, 23:1161-1169.

33. Dahiya N, Sherman-Baust CA, Wang TL, Davidson B, Shih le M, Zhang Y, Wood W, Becker KG, Morin PJ: MicroRNA expression and identification of putative miRNA targets in ovarian cancer. PLOS ONE 2008, 3:e2436.

34. Bhaumik D, Scott GK, Schokrpur S, Patil CK, Campisi J, Benz CC: Expression of microRNA-146 suppresses NF-kappaB activity with reduction of metastatic potential in breast cancer cells. Oncogene 2008, 27(42):5643-5647.

35. Verghese ET, AM Hanby, V Spiers, TA Hughes: Small is beautiful: microRNA and breast cancer - where are we now? J Pathol 2008, 215:214-221.

36. Iorio MV, Ferracin M, Liu CG, Veronese A, Spizzo R, Sabbioni S, Magri E, Pedriali M, Fabbri M, Campiglio M, Ménard S, Palazzo JP, Rosenberg A, Musiani P, Volinia S, Nenci I, Calin GA, Querzoli P, Negrini M, Croce CM: MicroRNA gene expression deregulation in human breast cancer. Cancer Res 2005, 65(16):7065-7070

37. MicroRNA signatures in human ovarian cancer: MicroRNA signatures in human ovarian cancer. Cancer Res 2007, 67(18):8699-8707.

38. Yanaihara N, Caplen N, Bowman E, Seike M, Kumamoto K, Yi M, Stephens RM, Okamoto A, Yokota J, Tanaka T, Calin GA, Liu CG, Croce CM, Harris CC: Unique microRNA molecular profiles in lung cancer diagnosis and prognosis. Cancer Cell 2006, 9(3):189-198.

39. Chan JA, Krichevsky AM, Kosik KS: MicroRNA-21 is an antiapoptotic factor in human glioblastoma cells. Cancer Res 2005, 65(14):6029-6033.

40. Lui WO, Pourmand N, Patterson BK, Fire A: Patterns of known and novel small RNAs in human cervical cancer. Cancer Res 2007, 67(13):6031-6043.

41. Rosenfeld N, Aharonov R, Meiri E, Rosenwald S, Spector Y, Zepeniuk M, Benjamin H, Shabes N, Tabak S, Levy A, Lebanony D, Goren Y, Silberschein E, Targan N, Ben-Ari A, Gilad S: MicroRNAs accurately identify cancer tissue origin. Nature Biotech 2008, 26(4):462-469.

42. Galardi S, Mercatelli N, Giorda E, Massalini S, Frajese GV, Ciafrè SA, Farace MG: miR-221 and miR-222 expression affects the proliferation potential of human prostate carcinoma cell lines by targeting p27kip1. J Biol Chem 2007, 282(32):23716-23724

43. Visone R, Russo L, Pallante P, De Martino I, Ferraro A, Leone V, Borbone E, Petrocca F, Alder H, Croce CM, Fusco A: MicroRNAs miR-221 and miR222 , both overexpressed in human thyroid papillary carcinomas, regulate p27Kip1 protein levels and cell cycle. Endocr Relat Cancer 2007, 14(3):791-798

44. Iorio MV, Casalini P, Piovan C, Di Leva G, Merlo A, Triulzi T, Ménard S, Croce CM, Tagliabue E: microRNA-205 regulates HER3 in human breast cancer. Cancer Res 2009, 69(6):2195-2200.

45. Yu F, Yao H, Zhu P, Zhang X, Pan Q, Gong C, Huang Y, Hu X, Su F, Lieberman J, Song E: let-7 regulates self renewal and tumorigenicity of breast cancer cells. Cell 2007, 131(6):1109-1123.

46. Chang TC, Wentzel EA, Kent OA, Ramachandran K, Mullendore M, Lee KH, Feldmann G, Yamakuchi M, Ferlito M, Lowenstein CJ, Arking DE, Beer MA, Maitra A, Mendell JT: Transactivation of miR-34a by p53 broadly influences gene expression and promotes apoptosis. Mol Cell 2007 26(5):745-752.

47. Jiang J, Lee EJ, Gusev Y, Schmittgen TD: Real-time expression profiling of microRNA precursors in human cancer cell lines. Nucleic Acids Res 2005, 33:5394-5403.
48. Smalheiser NR, Torvik VI: A population-based statistical approach identifies parameters characteristic of human microRNA-mRNA interactions. BMC Bioinformatics 2004, 5:139.

49. Enright AJ, John B, Gaul U, Tuschl T, Sander C, Marks DS: MicroRNA targets in Drosophila. Genome Biol 2003, 5(1):R1

50. Krek A, Grün D, Poy MN, Wolf R, Rosenberg L, Epstein EJ, MacMenamin P, da Piedade I, Gunsalus KC, Stoffel M, Rajewsky N: Combinatorial microRNA target predictions. Nat Genet 2005, 37(5):495-500

51. Grimson A, Farh KK, Johnston WK, Garrett-Engele P, Lim LP, Bartel DP: MicroRNA targeting specificity in mammals: determinants beyond seed pairing. Mol Cell 2007, 27(1):91-105.

52. Rajewsky N: microRNA target predictions in animals. Nat Genet 2006 38:58-13.

53. Sethupathy P, Megraw M, Hatzigeorgiou AG: A guide through present computational approaches for the identification of mammalian microRNA targets. Nat Methods 2006, 3(11):881-886.

54. Megraw M, Sethupathy P, Corda B, Hatzigeorgiou AG: miRGen: a database for the study of animal microRNA genomic organization and function. Nucleic Acids Res 2007, 35:D149-155.

55. Sethupathy P, Corda B, Hatzigeorgiou AG: TarBase: A comprehensive database of experimentally supported animal microRNA targets. RNA 2006, 12:192-197.

56. Didiano $D$, Hobert $O$ : Perfect seed pairing is not a generally reliable predictor for miRNA-target interactions. Nat Struct Mol Biol 2006, 13(9):849-851.

57. Smalheiser NR, Torvik VI: Complications in mammalian microRNA target prediction. Methods Mol Biol 2006, 342:115-127.

58. Garzon R, Calin GA, Croce CM: MicroRNAs in Cancer. Annu Rev Med 2009, 60:167-179.

59. Rathmell WK, Chen S: VHL inactivation in renal cell carcinoma: implications for diagnosis, prognosis and treatment. Expert Rev Anticancer Ther 2008, 8(1):63-73.

60. Calzada MJ, del Peso L: Hypoxia-inducible factors and cancer. Clin Trans/ Oncol 2007, 9(5):278-289.

61. Duda DG, Batchelor TT, Willett CG, Jain RK: VEGF-targeted cancer therapy strategies: current progress, hurdles and future prospects. Trends $\mathrm{Mol}$ Med 2007, 13:223-230

62. Ficarra V, Martignoni G, Maffei N, Brunelli M, Novara G, Zanolla L, Pea M, Artibani W: Original and reviewed nuclear grading according to the Fuhrman system: a multivariate analysis of 388 patients with conventional renal cell carcinoma. Cancer 2005, 103:68-75.

63. Boer JM, Huber WK, Sültmann H, Wilmer F, von Heydebreck A, Haas S, Korn B, Gunawan B, Vente A, Füzesi L, Vingron M, Poustka A: Identification and classification of differentially expressed genes in renal cell carcinoma by expression profiling on a global human 31,500-element cDNA array. Genome Res 2001, 11(11):1861-1870

64. Brannon AR, Reddy A, Seiler M, Arreola A, Moore DT, Pruthi RS, Wallen EM, Nielsen ME, Liu H, Ljungberg B, Zhao H, Brooks JD, Nathanson KL, Ganesan S, Bhanot G, Rathmell WK: Molecular Stratification of Clear Cell Renal Cell Carcinoma by Consensus Clustering Reveals Distinct Subtypes and Survival Patterns. Genes and Cancer in press.

65. Liu H, Alexe G, Juan D, Antes T, Liou L, Ganesan S, Bhanot G: A Procedure to identify MicroRNA gene targets in human kidney cancer. Proceedings of the 12th International Conference on Research in Computational Molecular Biology (RECOMB08): Singapore 2008.

66. Petillo D, Kort EJ, Anema J, Furge KA, Yang XJ, Teh BT: MicroRNA profiling of human kidney cancer subtypes. Int $J$ Oncol 2009, 35:109-114.

67. Tamura M, Gu J, Tran H, Yamada KM: PTEN gene and integrin signaling in cancer. J Natl Cancer Inst 1999, 91(21):1820-1828.

68. Hara S, Oya M, Mizuno R, Horiguchi A, Marumo K, Murai M: Akt activation in renal cell carcinoma: contribution of a decreased PTEN expression and the induction of apoptosis by an Akt inhibitor. Ann Oncol 2005 16(6):928-933

69. Zundel W, Schindler C, Haas-Kogan D, Koong A, Kaper F, Chen E, Gottschalk AR, Ryan HE, Johnson RS, Jefferson AB, Stokoe D, Giaccia AJ: Loss of PTEN facilitates HIF-1-mediated gene expression. Genes Dev 2000, 14(4):391-396.

70. Pantuck AJ, Seligson DB, Klatte T, Yu H, Leppert JT, Moore L, O'Toole T, Gibbons J, Belldegrun AS, Figlin RA: Prognostic relevance of the mTOR pathway in renal cell carcinoma: implications for molecular patient selection for targeted therapy. Cancer 2007, 109(11):2257-2267. 
71. Dromard M, Bompard G, Glondu-Lassis M, Puech C, Chalbos D, Freiss G: The putative tumor suppressor gene PTPN13/PTPL1 induces apoptosis through insulin receptor substrate-1 dephosphorylation. Cancer Res 2007, 67(14):6806-6813.

72. Felipe A, Vicente R, Villalonga N, Roura-Ferrer M, Martínez-Mármol R, Solé L, Ferreres JC, Condom E: Potassium channels: new targets in cancer therapy. Cancer Detect Prev 2006, 30(4):375-385.

73. Yamazaki K, Sakamoto M, Ohta T, Kanai Y, Ohki M, Hirohashi S: Overexpression of KIT in chromophobe renal cell carcinoma. Oncogene 2003, 22(6):847-52.

74. Dutta KK, Zhong Y, Liu YT, Yamada T, Akatsuka S, Hu Q, Yoshihara M, Ohara $\mathrm{H}$, Takehashi M, Shinohara T, Masutani H, Onuki J, Toyokuni S: Association of microRNA-34a overexpression with proliferation is cell typedependent. Cancer Sci 2007, 98(12):1845-1852.

75. Gumz ML, Zou H, Kreinest PA, Childs AC, Belmonte LS, LeGrand SN, Wu KJ, Luxon BA, Sinha M, Parker AS, Sun LZ, Ahlquist DA, Wood CG, Copland JA: Secreted frizzled-related protein 1 loss contributes to tumor phenotype of clear cell renal cell carcinoma. Clin Cancer Res 2007, 13(16):4740-4749.

76. Barbashina V, Salazar P, Holland EC, Rosenblum MK, Ladanyi M: Allelic losses at $1 p 36$ and $19 q 13$ in gliomas: correlation with histologic classification, definition of a 150-kb minimal deleted region on $1 \mathrm{p} 36$, and evaluation of CAMTA1 as a candidate tumor suppressor gene. Clin Cancer Res 2005, 11(3):1119-1128.

77. Henrich KO, Fischer M, Mertens D, Benner A, Wiedemeyer R, Brors B, Oberthuer A, Berthold F, Wei JS, Khan J, Schwab M, Westermann F: Reduced expression of CAMTA1 correlates with adverse outcome in neuroblastoma patients. Clin Cancer Res 2006, 12(1):131-138.

78. Thomasson M, Hedman H, Junttila TT, Elenius K, Ljungberg B, Henriksson $\mathrm{R}$ : ErbB4 is downregulated in renal cell carcinoma--a quantitative RTPCR and immunohistochemical analysis of the epidermal growth factor receptor family. Acta Oncol 2004, 43(5):453-459.

79. Camps C, Buffa FM, Colella S, Moore J, Sotiriou C, Sheldon H, Harris AL, Gleadle JM, Ragoussis J: hsa-miR-210 Is induced by hypoxia and is an independent prognostic factor in breast cancer. Clin Cancer Res 2008, 14(5):1340-1348.

80. Kulshreshtha R, Davuluri RV, Calin GA, Ivan M: A microRNA component of the hypoxic response. Cell Death Differ 2008, 15(4):667-671.

81. Baudis M: Genomic imbalances in 5918 malignant epithelial tumors: an explorative meta-analysis of chromosomal CGH data. BMC Cancer 2007, 7:226.

82. Yamaguchi A, Hori O, Stern DM, Hartmann E, Ogawa S, Tohyama M: Stress-associated endoplasmic reticulum protein 1 (SERP1)/Ribosomeassociated membrane protein 4 (RAMP4) stabilizes membrane proteins during stress and facilitates subsequent glycosylation. J Cell Biol 1999, 147(6):1195-1204.

83. Wilhelm M, Veltman JA, Olshen AB, Jain AN, Moore DH, Presti JC Jr, Kovacs G, Waldman FM: Array-based comparative genomic hybridization for the differential diagnosis of renal cell cancer. Cancer Res 2002, 62(4):957-960.

84. Korpal M, Lee ES, Hu G, Kang Y: The miR-200 family inhibits epithelialmesenchymal transition and cancer cell migration by direct targeting of E-cadherin transcriptional repressors ZEB1 and ZEB2. J Biol Chem 2008, 283(22):14910-14914.

85. Park SM, Gaur AB, Lengyel E, Peter ME: The miR-200 family determines the epithelial phenotype of cancer cells by targeting the E-cadherin repressors ZEB1 and ZEB2. Genes Dev 2008, 22(7):894-907.

86. Burk U, Schubert J, Wellner U, Schmalhofer O, Vincan E, Spaderna S, Brabletz T: A reciprocal repression between ZEB1 and members of the miR-200 family promotes EMT and invasion in cancer cells. EMBO Rep 2008, 9(6):582-589.

87. Nakada C, Matsuura K, Tsukamoto Y, Tanigawa M, Yoshimoto T, Narimatsu T, Nguyen LT, Hijiya N, Uchida T, Sato F, Mimata H, Seto M, Moriyama M: Genome-wide microRNA expression profiling in renal cell carcinoma: significant down-regulation of miR-141 and miR-200c. J Pathol 2008, 216(4):418-427

88. Dhanabal M, Wu F, Alvarez E, McQueeney KD, Jeffers M, MacDougall J, Boldog FL, Hackett C, Shenoy S, Khramtsov N, Weiner J, Lichenstein HS, LaRochelle WJ: Recombinant semaphorin 6A-1 ectodomain inhibits in vivo growth factor and tumor cell line-induced angiogenesis. Cancer Biol Ther 2005, 4(6):659-668.
89. Golub TR, Slonim DK, Tamayo P, Huard C, Gaasenbeek M, Mesirov JP, Coller H, Loh ML, Downing JR, Caligiuri MA, Bloomfield CD, Lander ES: Molecular classification of cancer: class discovery and class prediction by gene expression monitoring. Science 1999, 286:531-537.

90. Storey JD, Tibshirani R: Statistical significance for genomewide studies. Proc Natl Acad Sci USA 2003, 100(16):9440-9445.

doi: 10.1186/1752-0509-4-51

Cite this article as: Liu et al., Identifying mRNA targets of microRNA dysregulated in cancer: with application to clear cell Renal Cell Carcinoma BMC Systems Biology 2010, 4:51

\section{Submit your next manuscript to BioMed Central and take full advantage of:}

- Convenient online submission

- Thorough peer review

- No space constraints or color figure charges

- Immediate publication on acceptance

- Inclusion in PubMed, CAS, Scopus and Google Scholar

- Research which is freely available for redistribution

Submit your manuscript at www.biomedcentral.com/submit
C) Biomed Central 